(c) American Dairy Science Association, 2005.

\title{
Mammary Cell Turnover and Enzyme Activity in Dairy Cows: Effects of Milking Frequency and Diet Energy Density
}

\author{
J. Nørgaard, ${ }^{1}{ }^{\dagger}$ A. Sørensen, ${ }^{2, *}{ }^{,} \dagger$ M. T. Sørensen, ${ }^{1}$ J. B. Andersen, ${ }^{1}$ and K. Sejrsen ${ }^{1}$ \\ ${ }^{1}$ Danish Institute of Agricultural Sciences, Research Centre Foulum, \\ PO Box 50, DK-8830 Tjele, Denmark \\ ${ }^{2}$ Hannah Research Institute, Ayr KA6 5HL, United Kingdom
}

\section{ABSTRACT}

The aim of the study was to investigate the effects of diet energy density and milking frequency on mammary cell turnover and synthetic capacity in dairy cows. Experiment 1 used 20 dairy cows. From d 4 to wk 16 postpartum, the cows were fed either a low-energy density or a high-energy density diet. From d 4 through wk 8 , half of the cows in each group were milked 3 times $(3 \times)$ or 2 times $(2 \times)$ daily. From wk 9 to 16 , all cows were milked 2 times daily. Mammary biopsies were obtained at wk 8 and 16 postpartum. In experiment 2 , udders of 18 individual cows were milked diagonally $2 \times$ and $4 \times$, and biopsies were obtained after $7 \mathrm{~d}$. In experiment 1 , cows on the low-energy density diet yielded 17 and $24 \%$ less milk during wk 3 to 8 and wk 11 to 16 postpartum, respectively. Furthermore, at 8 wk postpartum, mammary enzyme activities tended to be lower and mammary cell proliferation was lower in cows on the low-energy density diet. Three times daily milking during the first 8 wk postpartum resulted in $11 \%$ higher milk yield. Mammary cell turnover or enzyme activities were not significantly affected at $8 \mathrm{wk}$. The $3 \times$ milking for 8 wk resulted only in a transient carryover effect on milk yield and neither cell turnover nor enzyme activities were significantly affected at 16 wk postpartum. In experiment 2 , mammary cell turnover and enzyme activity were unaffected after $7 \mathrm{~d}$ of $4 \times$ milking although milk yield increased by $18 \%$. We conclude that nutrient restriction affects mammary cell turnover and possible enzyme activity, and that tuning of negative feedback loops in response to filling of the gland may be the dominating effects of changes in milking frequency.

(Key words: mammary cell turnover, milking frequency, diet energy, dairy cow)

Received July 1, 2004.

Accepted November 10, 2004.

Corresponding author: K. Sejrsen; e-mail: kr.sejrsen@agrsci.dk.

*Present address: The Beatson Institute for Cancer Research, Glasgow G61 1BD, Scotland.

$\dagger \mathrm{JN}$ and AS contributed equally to this work.
Abbreviation key: ACC = acetyl-CoA carboxylase, FAS = fatty acid synthetase, $\mathbf{G T}=$ galactosyl transferase, $\mathbf{N} \times=\mathrm{N}$ times daily, $\mathbf{P C N A}=$ proliferating cell nuclear antigen.

\section{INTRODUCTION}

It is believed that the number of secretory cells in the mammary gland, as determined by the balance between cell proliferation and apoptosis, and the secretory activity of these cells determine milk yield and lactation persistency (Knight, 2000). However, methods to manipulate these cellular processes are not fully understood.

A restriction in nutrient availability results in decreased milk yield in dairy cows (Friggens et al., 1995; Lacy-Hulbert et al., 1999; Andersen et al., 2003). However, little is known about the cellular events leading to a decrease in milk yield although in rats it has been shown that a decline in the activity of the key enzyme acetyl-CoA carboxylase (ACC), which is involved in milk synthesis, may be affected (Flint and Vernon, 1998).

Increased milking frequency increases milk production (e.g., Erdman and Varner, 1995), and in some cases (Bar-Peled et al., 1995; Hale et al., 2003) but not all (Pearson et al., 1979), milk production remained elevated for a period after the treatment was terminated. On the cellular level, changes in milking frequency can lead to changes in mammary cell turnover as shown for cattle (Hillerton et al., 1990; Hale et al., 2003) and goats (Wilde et al., 1987; Li et al., 1999). The activity of key enzymes involved in milk synthesis has also been shown to change because of changes in milking frequency in goats (Wilde et al., 1986, 1987; Travers and Barber, 1993).

The timing of the onset of the cellular events after stimulation by increased milking frequency is not clear. Recent work of Hale et al. (2003) suggests that mammary cell proliferation may be stimulated after 6 but not $3 \mathrm{~d}$ of increased milking frequency whereas apoptosis may be transiently stimulated after $3 \mathrm{~d}$ of increased milking frequency. 
The main objectives of the present study were to examine the effects of diet energy density and milking frequency on mammary cell turnover and enzyme activity in dairy cows during early lactation. In addition, we examined whether 3 times daily $(3 \times)$ milking during the first $8 \mathrm{wk}$ postpartum causes a carryover effect on cell turnover and enzyme activity when milking frequency is returned to $2 \times$ milking. Finally, it was examined whether the effects of increased milking frequency are established after $1 \mathrm{wk}$ of treatment.

\section{MATERIALS AND METHODS}

\section{Animals and Diets}

Experiment 1. Experiment 1 used 20 HolsteinFriesian cows from the Research Centre Foulum dairy herd. The animals were blocked and allocated to the treatments primarily based on previous milk yield and parity. Parity ranged from 1 to 5 . Two total mixed diets composed of whole crop barley silage and concentrate were formulated. One diet (low-energy density diet) consisted of $75 \%$ silage and $25 \%$ concentrate, and the other (high-energy density diet) consisted of $25 \%$ silage and $75 \%$ concentrate. Protein and fat content did not differ between the 2 diets. The low-energy density diet was designed to limit energy intake by the cows, and the other diet was designed to allow the cows to maximize energy intake. Half of the cows were fed the high-energy density diet, and the other cows were fed the low-energy density diet. From calving, feed was offered ad libitum to both groups of cows. In addition to the nutritional treatment, milking frequency was increased from $2 \times$ to $3 \times$ from $4 \mathrm{~d}$ to $8 \mathrm{wk}$ postpartum in half of the cows in the low-energy density group and half of the cows in the high-energy density group. The remaining cows continued on $2 \times$ milking.

To examine possible carryover effects of milking frequency on milk yield and mammary cell turnover, milking frequency was reduced from $3 \times$ to $2 \times$ milking after $8 \mathrm{wk}$, and the nutritional treatment continued as before. The experiment was terminated after wk 16 postpartum.

Milk yield was measured 3 times per week and milk samples were collected for analysis of milk composition on a weekly basis.

A more thorough description of the experiment design, animals, and diet composition is published in Andersen et al. (2003).

Experiment 2. Eighteen Holstein-Friesian cows previously used in experiment 1 were included in this experiment. At wk 17 postpartum, milking frequency was increased from $2 \times$ to $4 \times$ in 2 of the udder quarters (rightfront/left-hind). The other udder quarters continued on $2 \times$ milking. Treatment continued for $7 \mathrm{~d}$. The nutri- tional regimen (high- or low-energy density diet) continued as in previous weeks. Milk yield was determined 2 and $1 \mathrm{~d}$ before the start of treatment and again on $\mathrm{d}$ 6 and 7 of treatment.

All procedures were conducted under the protocols approved by the Danish Animal Experiments Inspectorate and complied with the Danish Ministry of Justice Law no. 382 and Acts 739 concerning animal experimentation and care of experimental animals.

\section{Mammary Biopsies}

In experiment 1 , mammary biopsies were obtained from the front quarters after approximately $8 \mathrm{wk}$ of either $2 \times$ or $3 \times$ milking and again after a further approximately 8 wk of $2 \times$ milking for all cows, i.e., at approximately wk 16 postpartum. In experiment 2 , biopsies were obtained from front quarters milked $2 \times$ and $4 \times$ for $7 \mathrm{~d}$, within individual cows. All mammary biopsies were preceded by a subcutaneous injection of a local anesthetic ( $2 \mathrm{~mL}$ of xylocaine). Biopsies were obtained through the skin using a biopsy gun (ProMag 2.2, MDTECH, Gainesville, FL) loaded with a 14-g needle (Ultra-Core II, MDTECH). In one sample, up to $20 \mathrm{mg}$ of tissue was collected. A maximum of 3 samples were taken per udder quarter. A portion of the tissue was frozen immediately in liquid nitrogen for enzyme assays and a second portion was placed in $4 \%$ neutral buffered formalin for immunohistochemical detection of apoptosis and proliferating cell nuclear antigen (PCNA).

\section{Udder Volumes}

In experiment 1 , udder volumes were measured 13.9 $\pm 1.6 \mathrm{~d}$ postpartum, approximately 8 wk postpartum, and again approximately $16 \mathrm{wk}$ postpartum by polyurethane casting as performed by Dewhurst and Knight (1993). To get the best estimate, cows were injected with oxytocin and milked immediately before the volume measurement.

\section{Enzyme and DNA Assays}

The activities of ACC, fatty acid synthetase (FAS), and galactosyl transferase (GT) were measured as described by Wilde et al. (1986) under conditions in which activity was related linearly to amount of sample and incubation time. Results were expressed per milligram of DNA. The DNA concentration was measured in tissue homogenates by a fluorometric method using Picogreen dsDNA Quantification Kit (Molecular Probes, Eugene, OR) according to manufacturer's instructions. 


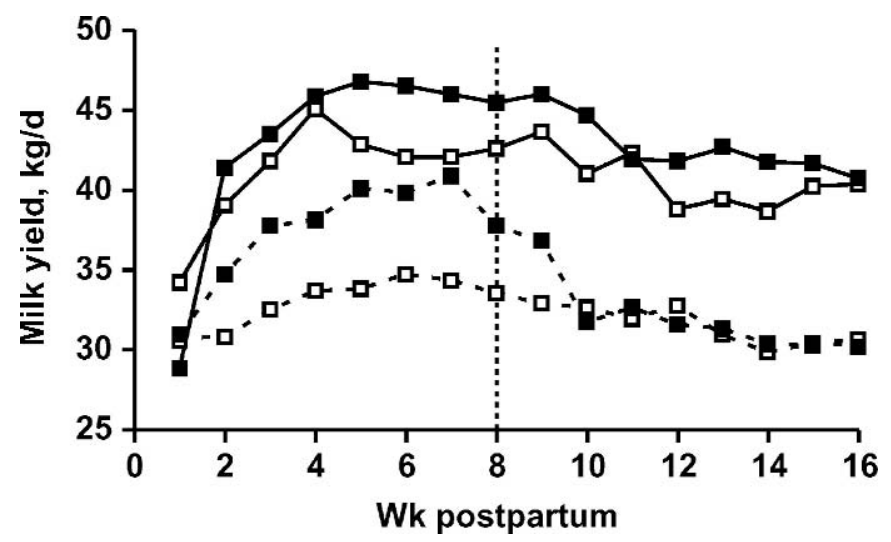

Figure 1. Milk yield during the experimental period, where cows were milked either 2 times daily ( $2 \times$, open squares) or 3 times daily (3×, filled squares) and fed either low- (dotted lines) or high-energy density diets (solid lines). The vertical line represents the time after which all cows were milked 2 times daily.

\section{Immunohistology}

Mammary tissue was fixed in $4 \%$ neutral buffered formalin, processed in paraffin, and sectioned at $4 \mu \mathrm{m}$. Mammary apoptosis was determined by terminal deoxynucleotidyl transferase dUTP nick end labeling of fragmented DNA using the commercial ApopTag Peroxidase in situ Apoptosis Detection Kit (Intergen Company, Purchase, NY). The principle of this assay is an enzymatic addition of digoxigenin-labeled nucleotide triphosphate to the $3^{\prime}-\mathrm{OH}$ ends of double and single stranded DNA. Labeled DNA fragments then bind to an antidigoxigenin antibody that is conjugated to a peroxidase reporter molecule. The percentage of cells staining positive for PCNA was used as a measure for cell proliferation because PCNA acts as a sliding clamp during DNA replication. For this purpose, a commercial kit was used (DAKO Corporation, Carpinteria, CA). Proliferative cells are labeled by using an antibody against PCNA, which is conjugated to a reporter molecule. Alveolar cells staining positive for apoptosis or PCNA were detected by microscopic examination. The examination was terminated when the fraction of positive cells was stable, although at least 500 alveolar cells were always counted.

\section{Statistical Analyses}

To allow for an adaptation period in experiment 1 , wk 1 and 2 were not included in the statistical analysis for milk yield and feed intake during the first $8 \mathrm{wk}$ of the experiment. Similarly, wk 9 and 10 were not included in the statistical analysis concerning milk yield and feed intake in wk 9 to 16 postpartum. The experimental design was a $2 \times 2$ factorial arrangement of treatments within 5 randomized complete blocks. Correlations were calculated as Pearson correlation coefficients (SAS Institute, 1999).

Effects of milking frequency and energy density in the diet within each of the 2 periods (wk 3 to 8 and wk 11 to 16) were analyzed by the MIXED procedure of SAS (SAS Institute, 1999) using the restricted maximum likelihood method and the following statistical model:

$$
\begin{aligned}
Y_{i j k l} & =\mu+\alpha_{i}+\beta_{j}+\gamma_{k}+\delta_{l}+(\gamma \delta)_{k l}+(\beta \gamma \delta)_{j k l} \\
& +(\beta \gamma)_{j k}+(\beta \delta)_{j l}+A_{i k l}+B_{i j k l}+\varepsilon_{i j k l},
\end{aligned}
$$

where $Y_{i j k l}$ is the dependent variable (milk yield, feed intake), $\mu$ is the least squares mean, $\alpha_{i}$ is the fixed effect of block $i\{i=1,2, \ldots 5\}, \beta_{j}$ is the fixed effect of week $j$ $\{j=3, \ldots 8$ and $11, \ldots 16\}, \gamma_{k}$ is the fixed effect of milking frequency $k\{k=2$ times daily, 3 times daily $\}, \delta_{l}$ is the fixed effect of energy density $l\{l=$ low, high $\},(\gamma \delta)_{k l}$, $(\beta \gamma \delta)_{j k l},(\beta \gamma)_{j k}$ and $(\beta \delta)_{j l}$ are the interactions between the 2 experimental factors, $A_{i k l}$ is the random effect of cow $i$ within group $k l, A_{i k l} \sim \mathrm{N}\left(0, \sigma_{\mathrm{A}}^{2}\right), B_{i j k l}$ is the random effect of repeated measurements and $B_{i j k l} \sim \mathrm{N}\left(0, \sigma_{\mathrm{B}}{ }^{2}\right)$, $\varepsilon_{i j k l}$ is the random residual variation, and $\left\{\varepsilon_{i j k l}\right\} \sim \mathrm{N}(0$, $\left.\sigma^{2}\right)$. No covariates were included in the statistical model because potential candidates (pretreatment yield and live weight) were included in the blocks by means of previous yield and parity.

Variables such as enzyme activities analyzed within the same week were analyzed using the GLM procedure of SAS (SAS Institute, 1999), where repeated measurements, the variable week, and interaction with week from model [1] were omitted.

In experiment 2, which had a split-plot arrangement, differences in milk yield, DNA concentration, and enzyme activities were evaluated by the MIXED procedure of SAS according to model [1] with the modification that the previous treatment $(2 \times$ or $3 \times$ milking) was included as a class variable. In addition, milk yield measured immediately before start of treatment was used as a covariate to estimate milk yield.

Apoptosis and cell proliferation was analyzed within week with the GENMOD procedure of SAS (SAS Institute, 1999) based on binomial distribution and logit transformation of data and with Pearson as the SCALE option according to the following model:

$$
\operatorname{logit}\left(P_{i j k}\right)=\mu+\alpha_{i}+\beta_{j}+\gamma_{k}+(\beta \gamma)_{j k},
$$

where $\operatorname{logit}\left(P_{i j k}\right)$ is $\log \left(P_{i j k} /\left(1-P_{i j k}\right)\right), \mu$ is the least squares mean, $\alpha_{i}$ is the fixed effect of block $i\{i=1,2, \ldots 5\}, \beta_{j}$ is the fixed effect of milking frequency $j\{j=2$ times daily, 3 times daily\}, $\gamma_{k}$ is the fixed effect of diet energy density $k\{k=$ low, high $\},(\beta \gamma)_{j k}$ is the interaction between milking frequency and energy density and 
Table 1. Milk yield and composition in cows milked either 2 times daily $(2 \times)$ or 3 times daily ( $3 \times)$ and fed either a low- or a high-energy density diet for the first 8 wk postpartum. At wk 8 postpartum, milking frequency was reversed from $3 \times$ to $2 \times$ and cows continued on either the low- or the high-energy density diet until 16 wk postpartum. ${ }^{1}$

\begin{tabular}{|c|c|c|c|c|c|c|c|c|c|}
\hline & & & & & & & & $P$ value & \\
\hline & & & Experin & tal group & & Model- & Milking & Eneroy & Frequency $\times$ \\
\hline & Week & $2 \times$ low & $3 \times$ low & $2 \times$ high & $3 \times$ high & $\mathrm{SE}$ & frequency & density & Energy \\
\hline Milk yield, kg/d & 3 to 8 & 33.8 & 39.1 & 42.7 & 45.7 & 5.1 & 0.07 & 0.003 & 0.61 \\
\hline & 11 to 16 & 31.1 & 31.1 & 39.9 & 41.8 & 3.9 & 0.54 & $<0.001$ & 0.55 \\
\hline Fat, $\%$ & 8 & 4.5 & 3.5 & 3.0 & 3.2 & 0.4 & 0.06 & $<0.001$ & 0.01 \\
\hline & 16 & 4.0 & 3.7 & 2.8 & 2.7 & 0.6 & 0.58 & 0.001 & 0.73 \\
\hline Lactose, $\%$ & 8 & 4.7 & 4.8 & 4.8 & 5.0 & 0.2 & 0.11 & 0.03 & 0.93 \\
\hline & 16 & 4.7 & 4.8 & 4.8 & 4.9 & 0.1 & 0.03 & 0.05 & 0.81 \\
\hline
\end{tabular}

${ }^{1}$ Values are least squares means; $\mathrm{n}=5$.

b(500, $\left.P_{i j k}\right)$. Model [2] used in experiment 2 did not include the variable block.

\section{RESULTS}

\section{Experiment 1}

Three cows coming from 3 of the 4 experimental groups were treated for mastitis within a week of biopsy sampling. Thus, there was no relationship between the incidence of mastitis and the experimental treatment.

Feed intake during wk 3 to 8 was 14.9 and $19.4(P<$ $0.001)$ and during wk 11 to 16 , it was 16.3 and $21.2(P$ $<0.001$ ) Scandinavian feed units per day (1 unit $=7.89$ $\mathrm{MJ}$ of $\mathrm{NE}_{\mathrm{L}}$ ) for the groups fed the low- and high- energy density diets, respectively.

Milk yield followed the normal lactation curve with yield reaching a peak between wk 4 and 6 postpartum (Figure 1). During wk 3 to 8 postpartum, cows fed the low-energy density diet had $17 \%$ lower milk yield $(P=$ 0.003 ) than cows fed the high-energy density diet. The milk yield of cows fed the low- energy density diet during wk 11 to 16 postpartum was $24 \%$ lower $(P<0.001)$ than that of cows fed the high-energy density diet (Table 1).
During wk 3 to 8 , increased milking frequency tended to increase $(P=0.07)$ milk yield $(11 \%)$, whereas no significant carryover effect of increased milking frequency was found on milk yield in wk 11 to $16(P=0.54)$. The milk composition in the weeks of biopsy sampling is shown in Table 1. For a thorough description of performance, refer to a companion paper by Andersen et al. (2003).

The first measurement of udder volume was not performed until d 14 postpartum due to udder edema. The udder volumes are given in Table 2. Feeding a lowenergy density diet did not result in smaller udders in wk 2,8 , or 16 . In wk 2 and 8 postpartum, udders were larger $(P<0.05)$ for cows milked $3 \times$ compared with those milked $2 \times$. This difference also tended $(P=0.06)$ to exist at wk 16. In spite of the larger udder volumes of the cows milked $3 \times$, there were no significant correlations between udder volume and milk yield $(\mathrm{r}=0.16$ and 0.26 for wk 8 and 16, respectively). Table 2 shows the concentration of DNA in mammary tissue. Neither energy density in the diet nor milking frequency had any significant effect on mammary DNA concentration. The DNA concentrations determined in this study were lower than previously reported for lactating cows (Ca-

Table 2. Udder volumes (L) and DNA concentration obtained from biopsies taken from cows milked either 2 times daily ( $2 \times$ ) or 3 times daily $(3 \times)$ and fed either a low- or a high-energy density diet for the first 8 wk postpartum. At wk 8 postpartum, milking frequency was reversed from $3 \times$ to $2 \times$ and cows continued on the low or the high-energy density diet until 16 wk postpartum. ${ }^{1}$

\begin{tabular}{|c|c|c|c|c|c|c|c|c|c|}
\hline & & & & & & & & $P$ valu & \\
\hline & & & Experi & tal group & & & & & \\
\hline & Week & $2 \times$ low & $3 \times$ low & $2 \times$ high & $3 \times$ high & SE & frequency & density & Energy \\
\hline Udder volume, $\mathrm{L}^{2}$ & 2 & 22.0 & 26.7 & 20.1 & 25.1 & 4.4 & 0.01 & 0.42 & 0.94 \\
\hline & 8 & 21.0 & 26.3 & 18.8 & 24.5 & 3.6 & 0.003 & 0.38 & 0.67 \\
\hline & 16 & 20.7 & 22.7 & 21.3 & 24.7 & 3.5 & 0.06 & 0.27 & 0.46 \\
\hline $\mathrm{DNA}, \mathrm{mg} / \mathrm{g}$ & 8 & 0.80 & 0.61 & 0.54 & 0.54 & 0.22 & 0.37 & 0.13 & 0.27 \\
\hline & 16 & 0.73 & 0.53 & 0.56 & 0.60 & 0.17 & 0.29 & 0.43 & 0.20 \\
\hline
\end{tabular}

\footnotetext{
${ }^{1}$ Values are least squares means; for $2 \times$ low, $3 \times$ low and $2 \times$ high, $n=5$ and for $3 \times$ high, $n=4$.

${ }^{2}$ For $3 \times$ low, $\mathrm{n}=4$.
} 
Table 3. Percentage and confidence limits of mammary epithelial cells undergoing apoptosis or proliferation (PCNA staining) in biopsies taken from cows milked either 2 times daily $(2 \times)$ or 3 times daily $(3 \times)$ and fed either a low- or a high-energy density diet for the first 8 wk postpartum. At wk 8 postpartum, milking frequency was reversed from $3 \times$ to $2 \times$ and cows continued on the low or the high-energy density diet until 16 wk postpartum. ${ }^{1}$

\begin{tabular}{|c|c|c|c|c|c|c|c|c|}
\hline & \multirow[b]{2}{*}{ Week } & \multicolumn{4}{|c|}{ Experimental group } & \multicolumn{3}{|c|}{$P$ value } \\
\hline & & $2 \times$ low & $3 \times$ low & $2 \times$ high & $3 \times$ high & $\begin{array}{l}\text { Milking } \\
\text { frequency }\end{array}$ & $\begin{array}{l}\text { Energy } \\
\text { density }\end{array}$ & $\begin{array}{l}\text { Frequency } \times \\
\text { Energy }\end{array}$ \\
\hline Apoptosis & 16 & $\begin{array}{l}0.48 \\
(0.14-1.64)\end{array}$ & $\begin{array}{l}0.24 \\
(0.04-1.36)\end{array}$ & $\begin{array}{l}0.32 \\
(0.07-1.44)\end{array}$ & $\begin{array}{l}0.08 \\
(0.01-1.75)\end{array}$ & 0.21 & 0.43 & 0.86 \\
\hline Proliferation & 16 & $\begin{array}{l}0.16 \\
(0.02-1.46)\end{array}$ & $\begin{array}{l}0.80 \\
(0.30-2.14)\end{array}$ & $\begin{array}{l}1.16 \\
(0.51-2.62)\end{array}$ & $\begin{array}{l}0.17 \\
(0.01-2.27)\end{array}$ & 0.65 & 0.99 & 0.002 \\
\hline
\end{tabular}

${ }^{1}$ Values are least squares means; for $2 \times$ low, $3 \times$ low and $2 \times$ high, $\mathrm{n}=5$, and for $3 \times$ high, $\mathrm{n}=4$. Confidence limits in parentheses $(P=0.05)$ are model-based approximate values from the statistical model [2] where block effect is omitted.

puco et al., 2001) and goats (Knight et al., 1990). The reason for this discrepancy is that DNA was measured in tissue homogenates suspended in a buffer with high salt $(\mathrm{NaCl})$ concentration, because subsequent measurements in some of the samples suspended in a buffer with one-hundredth the concentration of salt yielded twice as much DNA. There was not sufficient material in all samples for DNA measurement in a low- salt concentration buffer, and therefore the DNA measures from the high salt concentration buffer are used. However, because there was a significant $(P<0.05)$ correlation between the DNA measures obtained in the highand low-salt buffers, the DNA and the enzyme activity data (which are expressed per unit of DNA) are valid for comparisons between treatment groups.

At wk 8 postpartum, cows fed the low-energy density diet had considerably lower frequencies of cells staining positive for PCNA than had cows fed the high-energy density diet (Table 3), resulting in only $8.6 \%$ of the amount of cell proliferation $(P=0.001)$ in cows on the low-energy density diet compared with cows on the high-energy density diet. Diet energy density had no significant effects on mammary cell apoptosis at this time point. At wk 16 postpartum, neither cells staining positive for PCNA nor apoptosis were significantly different between cows fed the low or the high-energy density diet.

The 2 milking frequencies did not give rise to significant differences with regard to cells staining positive for apoptosis and PCNA at wk 8 or at wk 16 postpartum.

There were no interactions between the 2 experimental factors except for cell proliferation at wk 16 postpartum.

In general, there were no significant differences between treatment groups for enzyme activities per milligram of DNA measured in mammary biopsies taken at wk 8 and 16 postpartum (Table 4). However, at wk 8 there was a tendency $(P=0.14$ and 0.08 , respectively) toward greater GT activity in cows milked $3 \times$ and in cows fed the high-energy density diet than in cows from the 2 opposing treatments. Acetyl- CoA carboxylase and FAS showed increased activity in biopsies obtained in

Table 4. Enzyme activities of cows milked either 2 times daily $(2 \times)$ or 3 times daily $(3 \times)$ and fed either a low- or a high-energy density diet for the first $8 \mathrm{wk}$ postpartum. At wk 8 postpartum, milking frequency was reversed from $3 \times$ to $2 \times$ and cows continued on the low or the high-energy density diet until 16 wk postpartum. ${ }^{1}$

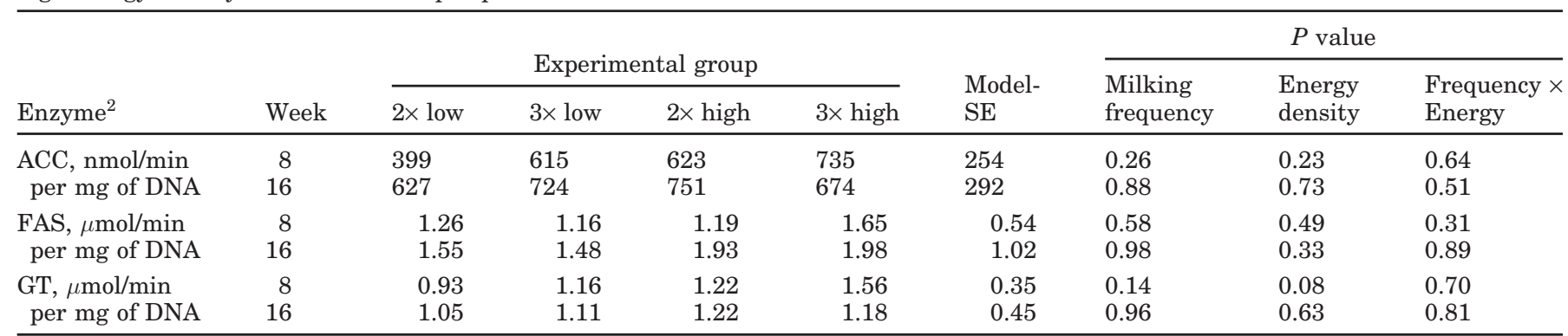

${ }^{1}$ Values are least squares means; for $2 \times$ low, $3 \times$ low and $2 \times$ high, $n=5$ and for $3 \times$ high, $n=4$.

${ }^{2} \mathrm{ACC}=$ Acetyl-CoA carboxylase; FAS = fatty acid synthetase; GT = galactosyl transferase. 
Table 5. Milk yield, and DNA concentration and enzyme activity in mammary biopsies after $7 \mathrm{~d}$ of treatment where cows were milked diagonally with 2 quarters milked 2 times daily $(2 \times)$ and the other 2 quarters 4 times daily (4×), and fed either a low- or a high-energy density diet in midlactation. ${ }^{1}$

\begin{tabular}{|c|c|c|c|c|c|c|c|c|}
\hline \multirow[b]{3}{*}{ Item $^{2}$} & \multirow{2}{*}{\multicolumn{4}{|c|}{ Experimental group }} & \multirow{3}{*}{$\begin{array}{l}\text { Model- } \\
\text { SE }\end{array}$} & \multicolumn{3}{|c|}{$P$ value } \\
\hline & & & & & & \multirow{2}{*}{$\begin{array}{l}\text { Milking } \\
\text { frequency }\end{array}$} & \multirow{2}{*}{$\begin{array}{l}\text { Energy } \\
\text { density }\end{array}$} & \multirow{2}{*}{$\begin{array}{l}\text { Frequency } \times \\
\text { Energy }\end{array}$} \\
\hline & $2 \times$ low & $4 \times$ low & $2 \times$ high & $4 \times$ high & & & & \\
\hline DNA, mg/g & 0.39 & 0.46 & 0.43 & 0.52 & 0.14 & 0.11 & 0.31 & 0.77 \\
\hline FAS, $\mu \mathrm{mol} / \mathrm{min}$ per $\mathrm{mg}$ of DNA & 2.64 & 2.88 & 3.07 & 2.43 & 1.26 & 0.54 & 0.98 & 0.19 \\
\hline $\mathrm{GT}, \mu \mathrm{mol} / \mathrm{min}$ per $\mathrm{mg}$ of DNA & 1.36 & 1.17 & 1.40 & 1.24 & 0.58 & 0.25 & 0.83 & 0.93 \\
\hline
\end{tabular}

${ }^{1}$ Values are least squares means; for $2 \times$ low and $4 \times$ low, $n=4$ and for $2 \times$ high and $4 \times$ high, $n=5$.

${ }^{2} \mathrm{FAS}=$ Fatty acid synthetase, GT = galactosyl transferase .

${ }^{3}$ Milk yield is corrected for yield the day before initiation of treatment

wk 8 compared with wk $16\left(P_{\mathrm{wk}}=0.14\right.$ and 0.06 for ACC and FAS, respectively). No interaction was observed between the 2 experimental factors. Correlations between lactose yield and GT activity were significant in wk $8(0.51, P=0.03)$, and correlations between fat yield and ACC and FAS were strongest in wk $16(0.37, P=$ 0.12 and $0.41, P=0.08$, respectively).

\section{Experiment 2}

One of the 18 cows was treated for mastitis after biopsy sampling, i.e., after termination of the experimental period, and one cow was treated during the days preceding the experimental period. The latter treatment is not expected to affect the results significantly.

There was no effect of diet energy density and no interaction between milking frequency and diet energy density for any of the measured variables.

Increasing milking frequency to $4 \times$ increased milk yield by $18 \%(P=0.005)$ after the $7 \mathrm{~d}$ of treatment. However, $7 \mathrm{~d}$ after initiation of this treatment neither enzyme activities nor cell turnover were affected (Table 5 and 6).

\section{DISCUSSION}

During wk 3 to 8 and 11 to 16 postpartum, cows fed the low- energy density diet had lower milk yield than cows fed the high- energy density diet. These results are in accordance with other studies concerning altered nutrient availability for lactating cows (Broster, 1974; Friggens et al., 1995; Lacy-Hulbert et al., 1999). Moreover, the positive effect of increased milking frequency on milk yield in both experiments is in agreement with other studies (Pearson et al., 1979; Amos et al., 1985; Rasmussen et al., 1989; Erdman and Varner, 1995). There was only a transient ( 1 to 2 wk) and not a longterm carryover effect of $3 \times$ milking on milk yield. The lack of a significant long-term carryover effect is in contrast to results of Bar-Peled et al. (1995) and Hale et al. (2003), who observed a positive long-term carryover effect of increased milking frequency in early lactation. A possible explanation for this discrepancy may be that the milking frequencies in these experiments were increased from $3 \times$ to $6 \times$ (Bar-Peled et al., 1995) and from $2 \times$ to $4 \times$ (Hale et al., 2003) compared with the increase from $2 \times$ to $3 \times$ milking in the present study.

Previously, a significant relationship between milk yield and udder volume has been reported (Knight, 2000). This relationship could not be confirmed in the present experiment. However, the majority of animals had udder edema at the time of the first measurement of udder volume. At wk 8, when the second measurement was taken, udder edema was still present in some of the cows. The measures of udder volume, therefore, may be unreliable due to edema.

Table 6. Percentage and confidence limits of mammary epithelial cells undergoing apoptosis or proliferation (PCNA staining) in biopsies taken from cows milked diagonally for $7 \mathrm{~d}$ with 2 quarters milked 2 times daily $(2 \times)$ and the other 2 quarters 4 times daily (4×) and fed either a low- or a high-energy density diet. ${ }^{1}$

\begin{tabular}{|c|c|c|c|c|c|c|c|}
\hline & \multirow{2}{*}{\multicolumn{4}{|c|}{ Experimental group }} & \multicolumn{3}{|c|}{$P$ value } \\
\hline & & & & & \multirow{2}{*}{$\begin{array}{l}\text { Milking } \\
\text { frequency }\end{array}$} & \multirow{2}{*}{$\begin{array}{l}\text { Energy } \\
\text { density }\end{array}$} & \multirow{2}{*}{$\begin{array}{l}\text { Frequency } \times \\
\text { Energy }\end{array}$} \\
\hline & $2 \times$ low & $4 \times$ low & $2 \times$ high & $4 \times$ high & & & \\
\hline Proliferation & $\begin{array}{l}0.15 \\
(0.07-0.33)\end{array}$ & $\begin{array}{l}0.18 \\
(0.09-0.36)\end{array}$ & $\begin{array}{l}0.16 \\
(0.08-0.31)\end{array}$ & $\begin{array}{l}0.18 \\
(0.10-0.34)\end{array}$ & 0.70 & 0.90 & 0.96 \\
\hline
\end{tabular}

\footnotetext{
${ }^{1}$ Values are least squares means; for $2 \times$ low and $4 \times$ low, $\mathrm{n}=4$ and for $2 \times$ high and $4 \times$ high, $\mathrm{n}=5$. Confidence limits in parentheses $(P=$
} $0.05)$ are model-based approximate values from the statistical model [2] where block effect is omitted. 


\section{Effects of Diet Energy Density on Mammary Cells}

To our knowledge, there is no previous research into the way a constraint on nutrient availability will affect mammary epithelial cells in ruminants. With regard to cell turnover, our results on PCNA at wk 8 postpartum indicate that epithelial cell proliferation was considerably lower in cows fed the low-energy density diet compared with cows fed the high-energy density diet, whereas epithelial cell apoptosis did not differ. Thus, our data indicate that the cell number of the mammary gland accommodates to nutrient availability, i.e., a decrease in nutrient availability will lead to a decrease in the number of mammary cells. Insulin-like growth factor-I, which is known to stimulate cell proliferation (Shamay et al., 1988), may at least partly be mediating this effect because IGF-I plasma concentration was 38\% lower in cows fed the low-energy density diet compared with those fed the high-energy density diet (Andersen et al., 2004). However, it should be noted that IGF-I interacts with IGF binding proteins and that there is a local mammary IGF-I synthesis (Flint et al., 2000).

Enzyme activities were numerically lower in mammary tissue from cows fed the low-energy density diet compared with the cows fed the high-energy density diet in experiment 1, but only the activity for GT measured 8 wk postpartum approached statistical significance. Taken together with the work of Flint and Vernon (1998), who observed a lower mammary ACC activity in rodents with feed intake restricted to 50 or $25 \%$ of ad libitum intake, the results suggest that the activity of some mammary enzymes may accommodate to the nutrient availability. However, because enzyme activity is expressed per unit of DNA originating from all cell types, it cannot be determined whether the change in activity originates from differentiated epithelial cells or is due to a change in the ratio between differentiated and undifferentiated cells or in the ratio between epithelial and stromal cells. The correlations observed between the yield of milk fat and the ACC and FAS enzymes and between the yield of lactose and the GT enzyme suggested that the enzyme activity of differentiated epithelial cells is accommodated to the nutrient availability.

The significantly higher enzyme activities observed for ACC and FAS in wk 16 compared with wk 8 postpartum are indicators of a change in ratio between differentiated epithelial cells and the other mammary cells or it may be an indicator of decreased epithelial cell efficiency with advancing lactation. Comparable results on enzyme activity with advancing lactation have been reported for well-fed goats (Wilde et al., 1986).

\section{Effects of Milking Frequency on Mammary Cells}

Udder volumes for cows milked $3 \times$ were significantly bigger than for cows milked only $2 \times$. This is in agreement with the work of Wilde et al. (1987) and Knight et al. (1990) in goats, whereas it is not consistent with the work on cows by Stelwagen and Knight (1997). The inconsistency among the results on udder volume may be due to inaccuracies related to udder edema in our data.

The number of cells undergoing apoptosis or staining positive for PCNA in wk 8 did not differ significantly between milking frequencies although apoptosis was numerically lowest and PCNA staining was numerically highest when cows were milked $3 \times$. In agreement (although not significant), Hillerton et al. (1990) found a higher number of cells per alveolus after 4 wk of $4 \times$ milking starting at wk 11 postpartum. Similarly, Hale et al. (2003) observed a tendency of numerically higher percentage of epithelial cells undergoing proliferation at $d 7$ and 14 postpartum when cows were milked $4 \times$ compared with $2 \times$. Thus, although the experimental foundation is weak, the present information indicates that increased milking frequency may increase cell proliferation and decrease apoptosis thus giving rise to relatively more mammary epithelial cells. In agreement with the work of Hillerton et al. (1990), there are indications that the activity of mammary cell enzymes may increase with the increase in milking frequency.

In experiment 2 , there were no clear short-term effects of milking $4 \times$ for $7 \mathrm{~d}$ during wk 17 postpartum on mammary cell turnover or enzyme activity, even though milk yield increased in this period. However, in the work of Hale et al. (2003) there were indications that apoptosis may be altered within $3 \mathrm{~d}$ and cell proliferation within $6 \mathrm{~d}$ after initiation of increased milking frequency.

The absence of clear effects on cell turnover and enzyme activity after a few days as well as after several weeks of altered milking frequency indicate that changes in milking frequency may affect other mechanisms. Thus, we suggest that negative feedback loops in response to filling of the gland are less activated because mammary glands are emptied more often with increased milking frequency. Candidates for having roles in these mechanisms are "feedback inhibitor of lactation," (Peaker et al., 1998) and serotonin (Matsuda et al., 2004).

In accordance with the lack of a long-term carryover effect of milking frequency on milk yield, there was also no significant long-term carryover effect on cell turnover or enzyme activity. 


\section{CONCLUSIONS}

A change in diet energy density for dairy cows will be accompanied by parallel changes in milk yield and mammary cell proliferation. In addition, a decrease in nutrient intake may be followed by a decrease in mammary enzyme activity. We therefore conclude that a restriction in nutrient availability to dairy cows has effects on mammary cell turnover and possibly on enzyme activity.

The increase in milk yield that was the consequence of the increase in milking frequency for 1 or 8 wk was not accompanied by significant changes in mammary cell turnover or enzyme activity. We therefore suggest that tuning of negative feedback loops in response to filling of the gland may be the dominating effects of changes in milking frequency. In accordance with the lack of a long-term carryover effect of milking frequency on milk yield, mammary cell turnover and enzyme activity were not affected in the long term.

\section{ACKNOWLEDGMENTS}

The authors thank lab technician Helle Handll Christensen for excellent technical assistance, and Ib Skovgaard for statistical advice.

\section{REFERENCES}

Amos, H. E., T. Kiser, and M. Loewenstein. 1985. Influence of milking frequency on productive and reproductive efficiencies of dairy cows. J. Dairy Sci. 68:732-739.

Andersen, J. B., N. C. Friggens, K. Sejrsen, M. T. Sørensen, L. Munksgaard, and K. L. Ingvartsen. 2003. The effects of low vs. high concentrate level in the diet on performance in cows milked two or three times daily in early lactation. Livest. Prod. Sci. 81:119-128.

Andersen, J. B., N. C. Friggens, T. Larsen, M. Vestergaard, and K. L. Ingvartsen. 2004. Effect of energy density in the diet and milking frequency on plasma metabolites and hormones in early lactating dairy cows. J. Vet. Med. A 51:52-57.

Bar-Peled, U., E. Maltz, I. Brukental, Y. Folman, Y. Kali, H. Gacitua, and A. R. Lehrer. 1995. Relationship between frequent milking or suckling in early lactation and milk production of high producing dairy cows. J. Dairy Sci. 78:2726-2736.

Broster, W. H. (1974) Response of the dairy cow to level of feeding. Bienn. Rev. Natl. Inst. Res. Dairy. 14-34.

Capuco, A. V., D. L. Wood, R. Baldwin, K. McLeod, and M. J. Paape. 2001. Mammary cell number, proliferation, and apoptosis during a bovine lactation: Relation to milk production and effects of bST. J. Dairy Sci. 84:2177-2187.

Dewhurst, R. J., and C. H. Knight. 1993. An investigation of the changes in sites of milk storage in the bovine udder over two lactation cycles. Anim. Prod. 57:379-384.

Erdman, R. A., and M. Varner. 1995. Fixed yield responses to increased milking frequency. J. Dairy Sci. 78:1199-1203.
Flint, D. J., E. Tonner, and G. J. Allan. 2000. Insulin-like growth factor binding proteins: IGF-dependent and independent effects in the mammary gland. J. Mammary Gland Biol. Neoplasia 5:65-73.

Flint, D. J., and R. G. Vernon. 1998. Effects of food restriction on the responses of the mammary gland and adipose tissue to prolactin and growth hormone in the lactating rat. J. Endocrinol. 156:299-305.

Friggens, N. C., G. C. Emmans, S. Robertson, D. G. Chamberlain, C. T. Whittemore, and J. D. Oldham. 1995. The lactational responses of dairy cows to amount of feed and to the source of carbohydrate energy. J. Dairy Sci. 78:1734-1744.

Hale, S. A., A. V. Capuco, and R. A. Erdman. 2003. Milk yield and mammary growth effects due to increased milking frequency during early lactation. J. Dairy Sci. 86:2061-2071.

Hillerton, J. E., C. H. Knight, A. Turvey, S. D. Wheatley, and C. J. Wilde. 1990. Milk yield and mammary function in dairy cows milked four times daily. J. Dairy Res. 57:285-294.

Knight, C. H. 2000. The importance of cell division in udder development and lactation. Livest. Prod. Sci. 66:169-176.

Knight, C. H., P. A. Fowler, and C. J. Wilde. 1990. Galactopoietic and mammogenic effects of long-term treatment with bovine growth hormone and thrice daily milking in goats. J. Endocrinol. 127:129-138.

Lacy-Hulbert, S. J., M. W. Woolford, G. D. Nicholas, C. G. Prosser, and K. Stelwagen. 1999. Effect of milking frequency and pasture intake on milk yield and composition of late lactation cows. J. Dairy Sci. 82:1232-1239.

Li, P., P. S. Rudland, D. G. Fernig, L. M. B. Finch, and C. J. Wilde. 1999. Modulation of mammary development and programmed cell death by the frequency of milk removal in lactating goats. J. Physiol. 519:885-900.

Matsuda, M., T. Imaoka, A. J. Vomachka, G. A. Gudelsky, Z. Hou, M. Mistry, J. P. Bailey, K. M. Nieport, D. J. Walther, M. Bader, and N. D. Horseman. 2004. Serotonin regulates mammary gland development via an autocrine-paracrine loop. Dev. Cell 6:193203.

Peaker, M., C. J. Wilde, and C. H. Knight. 1998. Local control of the mammary gland. Biochem. Soc. Symp. 63:71-79.

Pearson, R. E., L. A. Fulton, P. D. Thompson, and J. W. Smith. 1979. Three times a day milking during the first half of lactation. J. Dairy Sci. 62:1941-1950.

Rasmussen, M. D., C. C. Krohn, and E. S. Frimer. 1989. Produktion, reproduktion og sundhed ved 2, 3 eller 4 gange daglig malkning. Statens Husdyrbrugsfors $\emptyset$, meddelelse no. 728, 1-4.

SAS Institute. 1999. Release 8.2, SAS Institute Inc., Cary, NC.

Shamay, A., N. Cohen, M. Niwa, and A. Gertler. 1988. Effect of insulin-like growth factor I on deoxyribonucleic acid synthesis and galactopoiesis in bovine undifferentiated and lactating mammary tissue in vitro. Endocrinology 123:804-809.

Stelwagen, K., and C. H. Knight. 1997. Effect of unilateral once and twice daily milking of cows on milk yield and udder characteristics in early and late lactation. J. Dairy Res. 64:487-494.

Travers, M., and M. C. Barber. 1993. Isolation of goat acetyl-CoA carboxylase and fatty acid synthase genes in goat mammary gland. Comp. Biochem. Physiol B. 105:123-128.

Wilde, C. J., A. J. Henderson, and C. H. Knight. 1986. Metabolic adaptations in goat mammary tissue during pregnancy and lactation. J. Reprod. Fertil. 76:289-298.

Wilde, C. J., A. J. Henderson, C. H. Knight, D. R. Blatchford, A. Faulkner, and R. G. Vernon. 1987. Effects of long- term thricedaily milking on mammary enzyme activity, cell population and milk yield in the goat. J. Anim. Sci. 64:533-539. 